\title{
SOMATOSENSORY EVOKED POTENTIALS IN SPINAL CORD INJURED PATIENTS
}

\author{
By Paul E. Kaplan, ${ }^{1}$ M.D., F.A.C.P. and Joel S. Rosen, ${ }^{2}$ M.D. \\ 1 Associate Professor, Department of Rehabilitation Medicine, Northwestern University; \\ 2 Associate Professor (Clinical), Department of Rehabilitation Medicine, Northwestern \\ University
}

Key words: Somatosensory evoked potentials; Spinal cord injury.

Abstract. Out of 25 patients with traumatic spinal cord injuries, ten patients with complete and 15 incomplete (five serially) were evaluated with somatosensory evoked potentials. Clinical correlations are presented and discussed.

\section{Introduction}

IN I94I, Marshall et al. described the cerebral somatosensory projection of primates. Dawson (1950, I954, I956) first evoked somatosensory cerebral potentials (SEPs) in man by electrically stimulating the fingers. The evoked potentials had an amplitude of less than ro microvolts and were isolated at first by superimposition and later by averaging techniques from the contralateral cerebral hemisphere. Since then, SEPs have been isolated after stimulation of the upper extremities (Allison, 1962; Goff et al., 1962; Giblin, 1964; Halliday, 1967) and of the lower extremities (Liberson et al., I963; Bergamini et al., I965; Oester et al., I972; Tsumoto et al., 1972).

SEP values include transmission of the evoked potential through the spinal cord (Desmedt, I97I; Desmedt et al., I973). An involvement of the posterior column of the spinal cord has resulted in prolonged or absent SEP values (Halliday et al., 1963). The lower extremity SEP values reappeared (though delayed) after removal of an extradural benign tumour (Oester et al., 1972). The importance of the posterior column of the spinal cord in the transmission of SEPs has recently been confirmed (Cusick et al., 1979), especially with regard to the early components of the SEPs of the spinal cord (Wiederholt, 1978). SEPs then reflect the continuity of the posterior columns. However, none of the above observers had studied SEPs in a number of spinal cord injured patients. The object of this study was to explore the use of SEPs to evaluate the status of the spinal cord in spinal cord injured patients.

Patients (Table I)

\section{Methods and Materials}

Twenty healthy unpaid volunteers comprised the control group. None of the volunteers had any history of diabetes, alcoholism or any neurological disorder. Ten patients with traumatic spinal cord injuries (SCI) had no evidence of motor or sensory function bilaterally below the level of the lesion (complete SCI group). Another ten patients with traumatic spinal cord injuries had sensa-

Correspondence Address: Rehabilitation Institute of Chicago, 345 East Superior Street, Chicago, Illinois 606I I. 
TABLE I

\begin{tabular}{|c|c|c|c|c|}
\hline Group & Patients & $\begin{array}{c}\text { Age range } \\
\text { (median) }\end{array}$ & $\begin{array}{c}\text { Neurological } \\
\text { level }\end{array}$ & $\begin{array}{c}\text { Duration } \\
\text { (weeks) }\end{array}$ \\
\hline Control & 20 & $\begin{array}{c}28-49 \\
(36)\end{array}$ & none & - \\
\hline Complete spinal cord injuries & IO & $\begin{array}{c}20-47 \\
(40)\end{array}$ & $\mathrm{D}_{4}-\mathrm{D} 9$ & $4-8$ \\
\hline $\begin{array}{l}\text { Incomplete spinal cord } \\
\text { injuries }\end{array}$ & IO & $\begin{array}{c}24-55 \\
(34)\end{array}$ & $\mathrm{C}_{7}-\mathrm{L}_{2}$ & $4^{-8}$ \\
\hline Serial examination & 5 & $\begin{array}{c}20-34 \\
(27)\end{array}$ & $\mathrm{LI}_{\mathrm{I}}-\mathrm{L}_{4}$ & $\begin{array}{l}\text { 3-5 (first) } \\
6-9 \text { (second) }\end{array}$ \\
\hline
\end{tabular}

tion bilaterally below the level of the injury (incomplete SCI group). Five patients initially presented with traumatic spinal cord injuries had no sensation below the level of the lesion. All were initially evaluated from 3 to 5 weeks after the onset of the injury. All five patients were retested after an additional 3 to 5 weeks (serial exam group).

\section{Methods}

SEPs were obtained after electric stimulation of the median nerve according to the method of Kaplan (1978). The medial plantar nerve was stimulated with bipolar surface electrodes placed on the first toe. Square wave electric pulses were delivered (O.OI to I ms duration, I Hz frequency) of Ioo to $300 \mathrm{~V}$ intensity. SEPs were recorded from a monopolar electrode placed over the contralateral hemisphere, $4 \mathrm{~cm}$ below the vertex and $2 \mathrm{~cm}$ behind the line connecting the

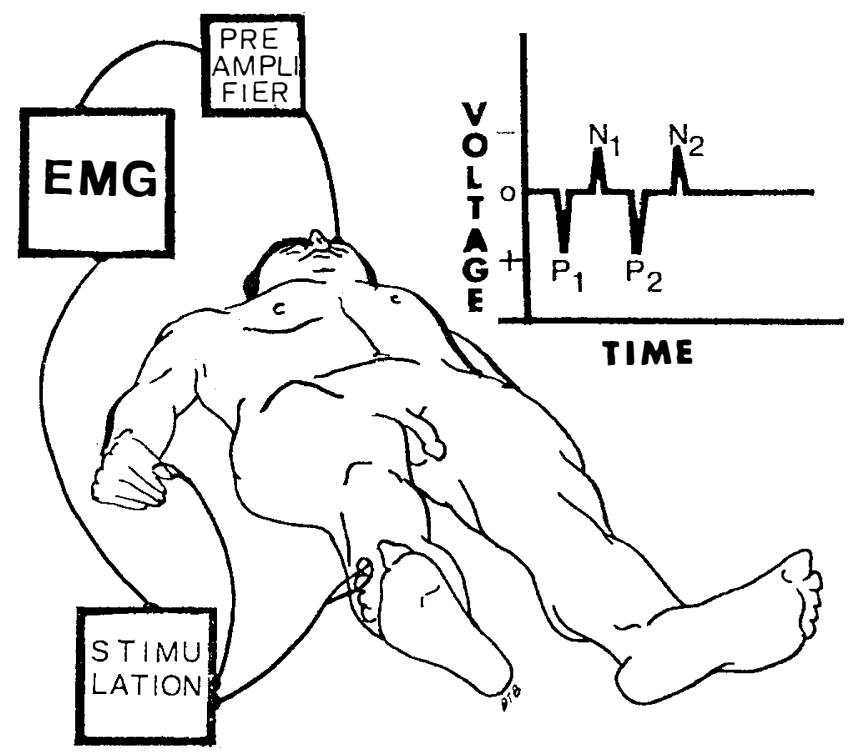

FIG. I

Determination of nomenclature of somatosensory cerebral evoked potentials. 
vertex to the ear. The reference electrode was fastened to the vertex and the ground electrode to the patient's forehead. A TECA model TE-4 electromyograph was used (high frequency filter $8 \mathrm{~K} \mathrm{~Hz}$, low frequency filter $\mathrm{I} \cdot 6 \mathrm{HZ}$ ). Bioelectric signals were averaged with a model AVM6 evoked potential averager. One hundred stimulations were averaged. The patient must be rested and quiet.

Latency values of the SEPs were measured from stimulation to departure from the isoelectric line and also to the peak of the first evoked potential. After stimulation of the median nerve, this evoked potential was the first negative response $\left(N_{1}\right)$. That for the medial plantar nerve was the first positive response $\left(P_{1}\right)$. This nomenclature system was used by Desmedt et al. (1973). The methodology is illustrated in Figure I. In each patient, both nerves were stimulated on the stronger side.

\section{Results}

The results of the control, incomplete SCI, and complete SCI groups are presented in Table II. SEPs were obtained in each of the control volunteers after stimulation of the median and medial plantar nerves.

In the incomplete SCI group, SEPs were obtained in each patient after stimulation of the median and medial plantar nerves. The values were not significantly different from the control population.

In the complete SCI group, SEPs were obtained in each patient after stimulation of the median nerves. However, no SEPs could be obtained after stimulation of the medial plantar nerves. The SEP values recorded after stimulation of the median nerves were not significantly different from control values.

The values for the serial examination group are presented in Table III. SEP values, not significantly different from control values, were obtained at the first and second evaluations after stimulation of the median nerves. SEPs could not be obtained after stimulation of the medial plantar nerves at the first examina-

TABLE II

\begin{tabular}{|c|c|c|c|}
\hline \multirow[t]{2}{*}{ Group } & \multirow[t]{2}{*}{ Nerve stimulated } & \multicolumn{2}{|c|}{ Somatosensory evoked potential } \\
\hline & & Latency (ms) & Peak latency (ms) \\
\hline Control & $\begin{array}{l}\text { Median } \\
\text { Medial plantar }\end{array}$ & $\begin{array}{ll}N_{1} & 18 \cdot 8 \pm 2 \cdot 2 \\
P_{1} & 39 \cdot \mathrm{I} \pm 3 \cdot \mathrm{I}\end{array}$ & $\begin{array}{ll}N_{1} & 2 \mathrm{I} \cdot 4 \pm \mathrm{I} \cdot 7 \\
P_{1} & 4 \mathrm{I} \cdot 2 \pm 2 \cdot 2\end{array}$ \\
\hline Complete spinal cord injuries & $\begin{array}{l}\text { Median } \\
\text { Medial plantar }\end{array}$ & $\begin{array}{cc}N_{1} & \text { I } 8.6 \pm 2.4 \\
P & \text { Absent }\end{array}$ & $\begin{array}{l}N_{1} 2 \mathrm{I} \cdot 3 \pm \mathrm{I} \cdot 6 \\
P_{1} \text { Absent }\end{array}$ \\
\hline Incomplete spinal cord injuries & $\begin{array}{l}\text { Median } \\
\text { Medial plantar }\end{array}$ & $\begin{array}{ll}N_{1} & 18.9 \pm 2 \cdot 3 \\
P_{1} & 38.9 \pm 3.0\end{array}$ & $\begin{array}{ll}N_{1} & 2 \mathrm{I} \cdot 0 \pm \mathrm{I} \cdot 7 \\
P_{1} & 40 \cdot 7 \pm 2 \cdot 5\end{array}$ \\
\hline
\end{tabular}

TABLE III

\begin{tabular}{cccc}
\hline Group patients & Nerve & \multicolumn{2}{c}{ Somatosensory evoked potentials $(\mathrm{ms})^{\star}$} \\
\cline { 3 - 4 } & & First exam. & Second exam. \\
Serial exam. (5) & Median & $2 \mathrm{I} \cdot \mathrm{I} \pm \mathrm{I} \cdot 3$ & $2 \mathrm{I} \cdot 5 \pm \mathrm{I} \cdot 6$ \\
& Medial plantar & Absent & $4 \mathrm{I} \cdot \mathrm{I} \pm 3 \cdot 7$ \\
\hline
\end{tabular}

Key: * Peak latencies only 
tion. However, SEP latency values, not significantly different from control values, were observed at the second examination. At the time of the re-examination, all five patients had sensation bilaterally below the neurological level.

\section{Discussion}

The median and medial plantar nerves when stimulated from the index finger or first toe send evoked responses to the spinal cord through the C6, 7, 8 and L4, 5 spinal nerve roots respectively (Warwick et al., 1973). Therefore, SEPs obtained after stimulation of the median nerve evaluated spinal cord function to the C8 neurological level. SEPs from the medial plantar nerve similarly evaluate function to the L5 neurological level. Indeed, SEPs mirror spinal cord function to the extent that a normal spinal cord conduction velocity of $55 \cdot \mathrm{I}-99 \mathrm{M} / \mathrm{sec}$ has been obtained using SEPs (Dorfman, 1977).

SEP values accurately reflected clinical findings in the serial exam group as well as in the complete and incomplete SCI groups. Early components of the SEP reflect activity in the posterior column of the spinal cord, in the medial lemniscus, in the venteroposteriolateral nucleus of the thalamus and in the sensory radiation to the cortex (Wiederholt, 1978). The cortical responses themselves have also been characterised. $N_{1}$ of the SEP after stimulation of the median nerve (Noel et al., 1975) has relatively short latencies, limited scalp distribution, prompt recovery and relative stability. They, therefore, are responses procedured by impulses of the presynaptic thalamocortical projection system (Bremer, 1958). $P_{1}$ of the SEP after stimulation of the medial plantar nerve has been positive rather than negative, of longer duration, and has had a longer recovery after maximal excitation (Towe, 1956; Tsumoto et al., 1972). Therefore, it is probably postsynaptic. Both $N_{1}$ and $P_{1}$ are generated posterior to the rolandic sulcus (Tsumoto et al., 1972). Therefore, SEPs have clear pathways from the spinal cord and may accurately reflect anatomical changes affecting dorsal column conduction within the spinal cord.

Future uses of SEPs in spinal cord injured patients might also involve the study of acutely injured patients. Evidence of significant deterioration would be shown in the acutely spinal cord injured patient who at first had a SEP from stimulation of the medial plantar nerve and then lost it. The disadvantages of doing the test in acutely injured patients are the requirements for a rested, quiet attitude of the patient and the need for space for the electromyograph, preferably away from electrical machines that could interfere with the bioelectric signal.

\section{SUMMARY}

A vertical and longitudinal study of SEPs in a control population (SEP median nerve $=19 \cdot \mathrm{I} \pm \mathrm{I} \cdot 7 \mathrm{~ms}$; SEP medial plantar nerve $=4 \mathrm{I} \cdot 2 \pm 2 \cdot 2 \mathrm{~ms}$ ), and in groups of spinal cord injured patients revealed that the SEP accurately reflected the clinical status of the patients. It was of use in documenting return of function in spinal cord injured patients.

\section{RÉSUMÉ}

Sortie de 25 malades souffrant de lésions de l'épine dorsale, Io malades avec complètes lésions et 15 malades avec incomplètes lésions ( 5 série) ont été examinés en utilisant les potentiels évoques corticaux. Les correlations cliniques sont présentées et interprétées. 


\section{ZUSAMMENFASSUNG}

25 Patienten mit traumatischen Wirbelsäuleverletzungen, Io Patienten mit totalen and I5 Patienten mit unvollständigen Verletzungen (5 Reihenweise), wurden durch Gebrauch von somatosensoricshem hervorgemfenem Potentiell untersucht. Klinisch gegenseitige Verhältnisse werden präsentiert und discutiert.

\section{REFERENCES}

Allison, R. (1962). Recovery functions of somatosensory evoked responses in man. Electroenceph. Clin. Neurophysiol., 14, 33 I-343.

Bergamini, L., Bergamasco, B., Fra, L., Gandiglio, G., Mombelli, A. M. \& Mutani, R. (I965). Somatosensory evoked cortical potentials in subjects with peripheral nervous lesions. Electromyography, 5, I2 I-I30.

Bremer, F. (1958). Cerebral and cerebellar potentials. Physiol. Rev., 38, 357-388.

Cusick, J. F., Myklebust, J. B., Larson, S. J. \& SAnCES, A. (I979). Spinal cord evaluation by cortical evoked responses. Arch. Neurol., 36, I40-I 43 .

Dawson, G. D. (1950). Cerebral responses to nerve stimulation in man. Brit. Med. Bull., 6, 326-329.

Dawson, G. D. (1954). A summation technique for the detection of small evoked potentials. Electroenceph. Clin. Neurophysiol., 6, 65-84.

Dawson, G. D. (1956). The relative excitability and conduction velocity of sensory and motor nerve fibres in man. F. Physiol. (Lord), 131, 436-45I.

DESMEDT, J. E. (I97I). Somatosensory cerebral evoked potentials in man. In Handbook of Electroencephalography and Clinical Neurophysiology, ed. by A. Remond. Amsterdam: Elsevier, Vol. 9, pp. 55-82.

Desmedt, J. E. \& NoEL, P. (I973). Average cerebral evoked potentials in the evaluation of lesions of the sensory nerves and of the central somatosensory pathway. In New Developments in Electromyography and Clinical Neurophysiology, ed. by J. E. Desmedt. Basel: Karger, Vol. 2, pp. 352-371.

DoRFMAN, L. J. (I977). Indirect estimation of spinal cord conduction velocity in man. Electroenceph. Clin. Neurophysiol., 42, 26-34.

Giblin, D. R. (1964). Somatosensory evoked potentials in healthy subjects and in patients with lesions of the nervous system. Ann. N. Y. Acad. Sci., II2, 93-I42.

GofF, W. R., Rosner, B. S. \& Allison, T. (I962). Distribution of cerebral somatosensory evoked responses in normal man. Electroenceph. Clin. Neurophysiol., 14, 697-713.

Halliday, A. M. (1967). Changes in the form of cerebral evoked responses in man associated with various lesions of the nervous system. Electroenceph. Clin. Neurophysiol., suppl, 25, I78-192.

Halliday, A. M. \& Wakefield, G. S. (1963). Cerebral evoked potentials in patients with dissociated sensory loss. F. Neurol. Neurosurg. Psychiat., 26, 2 I I-2 I 9.

KAPLAN, P. E. (I978). Blink reflex studies and somatosensory cerebral evoked potentials in patients with stroke and aphasia. EMG Clin. Neurophysiol., 18, I07-I I2.

Liberson, W. T. \& KIM, K. C. (I963). Mapping out of evoked potentials elicited by stimulation of median and peroneal nerves. (Abstract) Electroenceph. Clin. Neurophysiol., 15, 72I.

MARShALl, W. H., Wolsey, C. N. \& BARD, P. (I94I). Observations on cortical somatic sensory mechanisms of cat and monkey. Fournal of Neurophysiology, 4, pp. I-24.

NoEL, P., \& DESMEDT, J. E. (I975). Somatosensory cerebral evoked potentials after vascular lesions of the brain stem and diencephalon. Brain, 98, I 13-I28.

Oester, Y. T., Azlis, A. W. \& RodriqueZ, A. A. (I972). Possible diagnostic applications of sensory evoked potentials. Arch. Phys. Med. Rehabil., 5I, 2 I-27.

TowE, A. I. (1956). Evoked potentials and phenomena of the somatosensory cortex. Confin. Neurol. (Basel), 16, 333-360.

Tsumoto, T., Hirose, N., Nonaka, S. \& Takahashi, M. (1972). Analysis of somatosensory evoked potentials to lateral popliteal nerve stimulation in man. Electroenceph. Clin. Neurophysiol., 33, 379-388.

Warwick, R. \& Williams, P. L. (Editors) (1973). Gray's Anatomy, 35th British Edition. Philadelphia: W. B. Saunders Co., pp. IO40-4I, I056-58.

WIEDERHOLT, W. C. (1978). Recovery function of short latency components of surface and depth recorded somatosensory evoked potentials in the cat. Electroenceph. Clin. Neurophysiol., 45, 259-267. 